Published in final edited form as:

ACS Sens. 2016 May 27; 1(5): 607-613. doi:10.1021/acssensors.6b00043.

\title{
Label-free nanopore single-molecule measurement of trypsin activity
}

\author{
Shuo Zhou, Liang Wang, Xiaohan Chen, and Xiyun Guan* \\ Department of Chemistry, Illinois Institute of Technology, 3101 S Dearborn St, Chicago, IL 60616, \\ USA
}

\begin{abstract}
Trypsin is the most important digestive enzyme produced in the pancreas, and is a useful biomarker for pancreatitis. In this work, a rapid and sensitive method for the quantitative determination of trypsin activity is developed by using a biological alpha-hemolysin protein nanopore. Due to its much larger molecular diameter than the narrow pore constriction, trypsin itself cannot transport through the alpha-hemolysin channel. Hence, an indirect trypsin detection method is developed by monitoring its proteolytic cleavage of a lysine-containing peptide substrate. Based on the current modulations produced by the translocation of the substrate degradation products in the nanopore, the activity levels of trypsin could be determined. The method is rapid and highly sensitive, with picomolar concentrations of trypsin detected in minutes. In addition, the effects of cation and temperature on the sensor sensitivity, trypsin inhibition, and serum sample analysis are also investigated.
\end{abstract}

\section{TOC image}

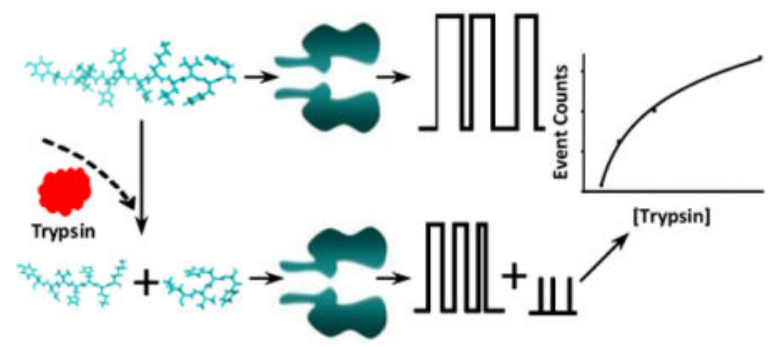

\section{Keywords}

trypsin activity; nanopore; label-free; biomarker; serum

Trypsin is a serine protease with 223 amino acid residues (M.W. $=23.8 \mathrm{kDa}$ ), which is the most important digestive enzyme produced in the pancreas as the inactive proenzyme

*Corresponding author: Xiyun Guan, Department of Chemistry, Illinois Institute of Technology, $3101 \mathrm{~S}$ Dearborn St, Chicago, IL 60616, USA, Tel.: +1 312567 8922; fax: +1 312567 3494, xguan5@iit.edu.

Supporting Information Available: The following file is available free of charge on the ACS Publications website. Additional figures, including the schematic illustration of trypsin nanopore sensor, typical trace segments for trypsin and TIBP, LVFF dose-response curve, time curve of substrate digestion, and serum sample analysis. 
trypsinogen ${ }^{1}$. Trypsin cleaves peptide bonds mainly at the carboxyl side of the lysine or arginine amino acid residue. Pancreatic trypsin production can be adversely affected by pathologies (e.g., pancreatitis), resulting in organ damage and release of enzyme into the blood. It is well known that the trypsin level is increased with some types of pancreatic diseases. For example, it has been reported that the mean trypsin concentration in a pancreas transplant patient's urine was $84.4 \mu \mathrm{g} / \mathrm{mL}$, while no trypsin was found in healthy person's urine $^{2}$; in healthy people, the serum trypsin concentration ranges from $140-400 \mathrm{ng} / \mathrm{mL}$, while the mean serum trypsin concentration in acute pancreatitis patients was $1,400 \mathrm{ng} / \mathrm{mL}^{3}$. Therefore, rapid and sensitive methods for trypsin detection, activity assay, and inhibitor screening are highly desired for the efficient diagnosis and treatment of pancreatic diseases.

Thus far, two major approaches have been developed for protease detection. They are affinity-based methods where an antibody or a protease template is usually employed ${ }^{4,5}$, and activity-based assay, which typically use a synthetic substrate consisting of a short peptide of known sequence to identify a specific protease and detect its activity ${ }^{6}$. While the conventional affinity-based methods allow for analysis of protease abundance, they are usually time-consuming and do not succeed in providing a measure of protease activity. Several such examples include radioimmunoassay, enzyme-linked immunosorbent assay, electrochemical immunoassay, molecular imprinting technology, etc ${ }^{4,5,7,8}$. However, activities of protease are tightly regulated through post-translational modifications. These modifications typically occur in the absence of any detectable change in protease abundance and are thus invisible to the conventional protease assay, leading to significant difference between overall abundance levels and activity of proteases. In contrast, measurement of protease activities can reveal valuable information regarding the type of chemical entities accepted by the protease as its potential substrates, and thus helps to better understand the properties and the catalytic mechanism of the protease ${ }^{9}$. Due to its potential applications in inhibitor screening, disease diagnosis, and drug development, measurement of protease activities has attracted increasing attention in the recent years, and numerous methods have been developed. Examples of activity-based trypsin assays include gel electrophoresis ${ }^{10}$, gelatin-based film techniques ${ }^{11}$, colorimetry ${ }^{6}$, chemiluminescence ${ }^{12}$, fluorescence ${ }^{13}$, and electrochemical methods ${ }^{14}$. However, most of these methods require the use of labels or sophisticated instruments.

In this work, we report a novel, rapid, and label-free nanopore stochastic sensing method to detect trypsin and quantitatively determine its activity. Nanopore sensing is an emerging amplification-free technique for measuring single molecules ${ }^{15-20}$. When analyte molecules pass through a single nanopore, they would induce ionic current modulations. These modulation events can be utilized to provide valuable information regarding both the concentration and the identity of the analyte, the former from the event frequency or event counts, while the latter from the event residence time and the extent of current blockage (i.e., amplitude). Since analytes pass through the nanopore at one molecule at a time, simultaneous detection and quantification of multiple components in a solution mixture can be readily accomplished using a single nanopore as long as the nanopore itself can provide enough resolution ${ }^{21}$. During the past decade, nanopore technology has shown great potential applications in numerous fields, such as medical diagnosis ${ }^{22-24}$, homeland security and biodefense $^{25,26}$, pharmaceutical screening ${ }^{27,28}$, and environmental protection ${ }^{29,30}$. 
It should be noted that nanopore stochastic sensors have been utilized to detect enzymatic reactions ${ }^{31-34}$. By using a substrate (tethered or untethered) for a particular enzyme/protease and monitoring its translocation in the nanopore, we can readily identify whether the sample contains the target enzyme/protease or not. Specifically, the appearance of new types of events or the change in the event frequency in the nanopore indicates the presence of the target analyte. However, to the best of our knowledge, until now, there is no report of employing nanopore sensing technology for the quantitative determination of enzyme/ protease activity.

\section{Experimental Section}

\section{Materials and reagents}

The trypsin substrate, $\beta$-amyloid (10-20) peptide (sequence: YEVHHQKLVFF; PI: 7.7), was synthesized from American Peptide Company (Sunnyvale, CA). The two substrate cleavage fragments (peptide sequence: LVFF and YEVHHQK) were purchased from WatsonBio (Houston, TX), and Biomatik Corporation (Wilmington, DE), respectively. All the other chemicals, including Trypsin (from bovine pancreas, its optimum $\mathrm{pH}$ ranging from 7 to 9), were obtained from Sigma-Aldrich (St. Louis, MO). All of the solutions were prepared with HPLC-grade water (ChromAR, Mallinchkrodt Baker). The concentrations of the stock solutions were $0.5 \mathrm{mM}, 10 \mathrm{mM}, 0.5 \mathrm{mM}$, and $100 \mu \mathrm{g} / \mathrm{mL}$ for the peptide substrate, its two breakdown products (peptides YEVHHQK and LVFF), and trypsin, respectively. All these solutions were kept at $-20{ }^{\circ} \mathrm{C}$ before and immediately after use.

\section{Bilayer experiment and data analysis}

The procedure of electrical recording has been described previously (see Supporting Information, Fig. S-1 for a schematic illustration of the protein nanopore sensing system) ${ }^{30}$. Briefly, nanopore experiments were performed in a two-compartment chamber separated by a Teflon film (Goodfellow Malvern, PA) having a $150 \mu \mathrm{m}$ diameter orifice, on which planar bilayer was formed using 1, 2-diphytanoylphosphatidylcholine (DPhPC, Avanti Polar Lipids, Alabaster, AL, USA) according to the Montal-Mueller method ${ }^{35}$. Single channel recordings were carried out at $24 \pm 1{ }^{\circ} \mathrm{C}$ using engineered a-hemolysin (aHL) (M113F) 7 protein pores ${ }^{31}$ under symmetric buffer conditions, with each compartment containing a 2.0 $\mathrm{mL}$ electrolyte solution (1.0 M NaCl,10 mM Tris, $\mathrm{pH} 7.5$ ). With the exception of the aHL protein nanopore (approximately $0.2-2.0 \mathrm{ng} / \mathrm{mL}$ ), which was added to the grounded cis side of the chamber device, other substances were introduced to the trans chamber. Currents were recorded with an Axopatch 200B amplifier (Molecular Devices, Sunnyvale, CA), filtered with a four-pole low-pass Bessel filter at $5 \mathrm{KHz}$, and then digitized with a Digidata 1440A converter (Molecular Devices) at a sampling frequency of $50 \mathrm{KHz}$. The signatures of current modulations (or events), including the mean values of residual currents, residence times, and amplitude histograms, were obtained using Clampfit 10.3 software (Molecular Devices).

\section{Serum sample analysis}

$100 \mathrm{ng}$ trypsin was spiked into $2 \mu \mathrm{L}$ bovine serum (Thermo Fisher Scientific, Grand Island, NY) to create a mock serum sample. The simulated serum sample, $4.24 \mu \mathrm{L}$ reaction buffer (containing $1 \mathrm{mM} \mathrm{NaCl}$ and $10 \mathrm{mM}$ tris, $\mathrm{pH}=7.5$ ), and $20 \mu \mathrm{L} 0.5 \mathrm{mM}$ substrate $\beta$-amyloid 
(10-20) peptide were mixed and incubated for 30 minutes in water bath at $22{ }^{\circ} \mathrm{C}$. Then, the mixture was introduced to the trans chamber compartment for single channel recording. The control sample was prepared using the same concentrations and volumes of trypsin and the substrate peptide but with HPLC water instead of the serum. Both experiments were carried out using the $(\mathrm{M} 113 \mathrm{~F})_{7}$ a-hemolysin protein nanopore in an electrolyte buffer solution (1.0 $\mathrm{M} \mathrm{NaCl}, 10 \mathrm{mM}$ Tris, $\mathrm{pH}=7.5$ ).

\section{Results and discussion Detection of trypsin}

The principle for nanopore detection of trypsin is shown in Scheme 1. When there is no presence of trypsin, the substrate peptide molecules pass through the nanopore giving one signal reading, i.e., a type of characteristic current modulation events with unique residence time and blockage amplitude. By contrast, if trypsin is present in the solution, acting like a scissors, cuts the peptide molecules, the cleavage products produce entirely different current modulations from those of the substrate. A comparison of these events quantifies the trypsin enzymatic activity.

As proof of concept, our effort in the development of trypsin nanopore sensor was initially conducted at $-40 \mathrm{mV}$ in an electrolyte buffer solution containing $1 \mathrm{M} \mathrm{NaCl}$ and $10 \mathrm{mM}$ Tris $(\mathrm{pH} 7.5)$. The mutant aHL $(\mathrm{M} 113 \mathrm{~F})_{7}$ protein nanopore was used as the stochastic sensing element, while $\beta$-amyloid (10-20) peptide (sequence: YEVHHQKLVFF, $5 \mu \mathrm{M}$ ) was employed as the substrate. It is well known that catalytic cleavage of peptides by trypsin occurs after positively charged lysine or arginine amino acid residues, while the aHL $(\mathrm{M} 113 \mathrm{~F})_{7}$ protein pore has been shown to offer an improved sensor resolution/sensitivity (e.g., prolonged event residence time for the analytes) over the wild-type aHL pore ${ }^{36}$. The $-40 \mathrm{mV}$ voltage and $5 \mu \mathrm{M}$ substrate were chosen based on our previous work ${ }^{37}$. Specifically, at this applied potential bias, peptide translocation in the aHL nanopore showed a largest signal-to-noise ratio (i.e., small-amplitude, transient, rarely-observed background spikes vs. large-amplitude, long-duration, and frequent peptide blockage events), and hence, the nanopore sensor offered the best resolution. On the other hand, $5 \mu \mathrm{M}$ YEVHHQKLVFF could produce enough translocation events for statistical data analysis using a relatively short recording time and a relatively small amount of expensive peptide substrate. The experimental results were summarized in Fig. 1. It is apparent that, with the addition of $\beta$ amyloid (10-20) peptide alone in the trans chamber compartment, only one major type of current modulations was observed. These current blockage events had a mean residence time of $\sim 0.31 \mathrm{~s}$ and a mean residual current of $\sim-2.25 \mathrm{pA}$, suggesting the translocation of the peptide substrate through the nanopore. By contrast, after trypsin was additionally added to the trans chamber, two types of new events (blue and yellow marked ones in Figs. 1b and 1c) appeared. These new events presented much smaller residence times and amplitudes than those of the peptide substrate (Figs. 1a, 1b, and 1c). Although they themselves had similar residence time $(\sim 1.1 \mathrm{~ms})$, the two types of new events could be well separated and differentiated based on their significantly different residual currents ( -5 pA vs. $\sim-12 \mathrm{pA}$ ). Furthermore, our experiments showed that the frequencies of the new events increased with the recording time and with the increased concentration of added trypsin, a clear indication 
that they were attributed to the products formed by the trypsin's cleavage of the $\beta$-amyloid (10-20) peptide, i.e., YEVHHQK and LVFF, respectively. It should be noted that, the possibility that these new events were attributed to trypsin was ruled out by the control experiment (Supporting Information, Fig. S-2), in which trypsin itself couldn't produce translocation events in the nanopore as single-stranded nucleic acids and short peptides $\operatorname{did}^{19,36}$. This result not only agreed very well with the fact that trypsin has a larger spherical molecular diameter than that of the aHL transmembrane domain ( $38 \AA$ vs. $20 \AA$ ) so that it can not enter the protein pore ${ }^{38,39}$, but also suggested that trypsin would not be denatured and pulled through the nanopore under our experimental condition, i.e., at a small applied voltage bias of $-40 \mathrm{mV}$.

\section{Detection limit of the nanopore trypsin sensor}

Under the current experimental conditions (i.e., with the a-hemolysin $(\mathrm{M} 113 \mathrm{~F})_{7}$ pore, at an applied potential of $-40 \mathrm{mV}$, in $1 \mathrm{M} \mathrm{NaCl}$ buffer solution of $\mathrm{pH} 7.5$ ), a series of experiments was carried out to investigate the proteolytic cleavage of the substrate peptide $\beta$-amyloid (10-20) by trypsin, where we kept the concentration of the substrate constant $(5 \mu \mathrm{M})$, but varied the trypsin concentration (ranging from 2 to $100 \mathrm{ng} / \mathrm{mL}$ ). Similar to the observation we made in the previous section, in addition to the substrate events, two new types of current modulations were identified in all of the different trypsin concentration situations, providing further evidence that these events were attributed to the substrate degradation products. It should be noted that, after trypsin digestion of the substrate, in principle, the two cleavage products should have identical concentrations. However, due to the length and structure difference in these two peptide fragments, the event frequencies for their translocation in the nanopore might vary greatly, which has been demonstrated in our previous study ${ }^{36}$. Since the LVFF events were significantly more frequent than the YEVHHQK events, for convenience, only LVFF events were included in the data analysis. It is worth mentioning that, one advantage of obtaining enzyme kinetic and thermodynamic information based on the substrate degradation product signal instead of the substrate signal (which is commonly used by various conventional enzyme assays) is that the substrate cleavage site can be utilized as a useful parameter to improve the selectivity and the accuracy of the protease assay. In the event that other potential interfering proteases and the target trypsin cleave the substrate peptide at different positions, their generated different peptide fragments allow the differentiation between the target analyte from false positives. The plot of the number of LVFF events collected in a 30-min recording versus the trypsin concentration is summarized in Fig. 2. It was found that the detection limit for trypsin (which is defined as the trypsin concentration corresponding to three times the standard deviation of a blank signal) in a 30minute reaction period was $1.4 \mathrm{ng} / \mathrm{mL}$ (corresponding to $59 \mathrm{pM}$ ). Such a detection limit is as good as those (ranging from $100 \mathrm{ng} / \mathrm{mL}$ to $2 \mathrm{ng} / \mathrm{mL}$ ) of other various sensitive trypsin detection methods developed thus far $5,6,13,14$, and more than good enough for analysis of trypsin in clinical samples (note that the trypsin concentration in healthy people's serum ranges from $140-400 \mathrm{ng} / \mathrm{mL}$ ).

\section{Effects of metal ions and temperature on the nanopore sensor sensitivity}

It has been well-documented that the existence of $\mathrm{Ca}^{2+}$ ions in the solution would benefit the process of proteolytic reaction catalyzed by trypsin ${ }^{40}$. In fact, trypsin itself is a protein, it is 
capable of digesting itself. However, this autolysis process (more commonly known as selfdigestion) can be prevented by $\mathrm{Ca}^{2+}$ ions (due to their binding to trypsin). In addition, $\mathrm{Ca}^{2+}$ ions can also promote the formation of active trypsin from trypsinogen, the protein produced in its inactive form within the pancrease of humans ${ }^{41-43}$. To examine whether the existence of $\mathrm{Ca}^{2+}$ ions in the electrolyte solution could improve the nanopore sensor sensitivity for trypsin analysis, the effect of $\mathrm{Ca}^{2+}$ ions on the trypsin cleavage of the $\beta$-amyloid (10-20) peptide was further investigated. Our experimental results showed that, compared with the electrolyte solution without $\mathrm{Ca}^{2+}$, the buffer solution containing additional $5 \mathrm{mM} \mathrm{Ca}^{2+}$ ions would result in a (19.5 \pm 0.5$) \%$ increase in the number of LVFF events (Fig. 3a), confirming that $\mathrm{Ca}^{2+}$ indeed enhanced the sensor sensitivity.

The influence of temperature on trypsin activity was further investigated since enzymatic activity is temperature dependent. Briefly, $1 \mu \mathrm{L}$ of $100 \mu \mathrm{g} / \mathrm{mL}$ trypsin and $20 \mu \mathrm{L} 5 \mathrm{mM} \beta$ amyloid (10-20) peptide was incubated for 30 min using a water bath at $22^{\circ} \mathrm{C}$ and $37^{\circ} \mathrm{C}$, respectively. Then, the mixture was introduced to the trans compartment of the nanopore sensing chamber for single-channel recording. The final concentrations of trypsin and the substrate peptide in the nanopore sensor were $50 \mathrm{ng} / \mathrm{mL}$ and $5 \mu \mathrm{M}$, respectively. Our experiments (Fig. 3b) showed that the frequency of LVFF events increased by $(113 \pm 20) \%$ as the temperature of incubation increased from $22{ }^{\circ} \mathrm{C}$ to $37^{\circ} \mathrm{C}$.

\section{Measurement of trypsin activity}

In order to measure the activity of trypsin by nanopore analysis, a modified version of the universal protease activity assay ${ }^{44}$ was developed. Briefly, peptide LVFF, one of the cleavage products of the substrate $\beta$-amyloid (10-20) peptide, was custom synthesized, and the doseresponse curve (event counts vs. peptide concentration) for its translocation in the nanopore was constructed (Supporting information, Fig. S-3). By comparing the number of events of LVFF generated by the trypsin cleavage of $\beta$-amyloid (10-20) with this calibration curve, we could obtain the concentration of LVFF in the enzymatic reaction mixture solution.

Then, the activity of trypsin could be determined in terms of Units, which is the amount of micromoles of the peptide LVFF fragment released from the substrate per minute. The activities of trypsin at various concentrations were summarized in Table 1. From the table, we could see that, with the increase in the concentration of the trypsin (freshly bought from Sigma), its activity indeed increased. However, the percent increase in trypsin activity was not linearly related to that of trypsin concentration, but gradually decreased as the concentration of trypsin increased. One of the main reasons might be because trypsin cleaved the substrate so rapidly that the concentration of the substrate was low in our trypsin assay experiments, especially at high trypsin concentrations. This interpretation is supported by the time curve of substrate digestion (Supporting Information, Figure S-4), where we found that under our experimental condition ( $5 \mu \mathrm{M}$ substrate and $100 \mathrm{ng} / \mathrm{mL}$ trypsin), $70 \%$ of the substrate was digested in one hour. In principle, in order to determine the protease activity accurately, a large excess of substrate over enzyme should be used. In addition, to show the difference between trypsin abundance and trypsin activity, the same substrate digestion experiment was performed using $50 \mathrm{ng} / \mathrm{mL}$ trypsin, with its stock solution prepared one year ago and stored at $-80{ }^{\circ} \mathrm{C}$ freezer. Our experimental results (data not 
shown) showed that the substrate cleavage events were rarely observed, thus confirming that abundance and activity were indeed different concepts.

\section{Trypsin inhibition and simulated serum sample analysis}

Proteases are valuable diagnostic or prognostic markers for a variety of diseases and conditions, such as inflammation, cardiovascular diseases and cancer, and are becoming increasingly important targets for drug discovery. For example, inhibitors of well-established protease targets such as $\mathrm{HCV}$ protease and HIV protease have been widely used to treat hepatitis $\mathrm{C}$ and AIDS. To demonstrate the feasibility of utilizing our developed nanopore sensing platform as a screening tool for protease inhibitors, trypsin cleavage of the $\beta$ amyloid (10-20) peptide was further investigated in the presence of the trypsin inhibitor from bovine pancreas (TIBP), a small globular protein with 58 amino acid residues (M. W. = $6.5 \mathrm{kDa})^{45}$. Similar to the observation we made in the interaction between trypsin and the ahemolysin nanopore, due to its large molecular size, low concentrations of TIBP (e.g., 0.125 $\mathrm{nM}$, Supporting Information, Fig. S-2) would rarely produce translocation events with blockage amplitudes similar to those of the substrate degradation products, thus not interfering with our investigation of peptide translocation in the nanopore. In principle, TIBP would bind to trypsin, thus inhibiting trypsin cleavage of $\beta$-amyloid (10-20) peptide. Therefore, compared with the situation without trypsin inhibitor, the presence of TIBP in the solution would lead to a decrease in the event frequency of the substrate cleavage products. Our experiments (Fig. 4) showed that, in the absence of TIBP, 2075 LVFF events were observed in a 456-s single-channel recording. In contrast, in the presence of TIBP, we only identified 1030 LVFF events in the same time frame. The results confirmed that TIBP could indeed inhibit trypsin activity.

To demonstrate the application of our developed nanopore sensor for potential clinical sample analysis, trypsin was spiked into the bovine serum to create a mock serum sample. It should be noted that, one of the challenges to analyze clinical samples using the protein nanopore sensor is that the amphiphilic proteins in serum samples might disturb the lipid bilayer $^{34}$ using the vertical design used in this work, although it has been successfully used in other horizontal conducting chambers. ${ }^{24}$ One feasible approach to overcome this difficulty is to use spin-columns to remove interfering blood serum components ${ }^{46}$. In our previous work, we found that by incubating mock serum samples with peptide substrates, and then analyzing the mixture solution using the protein nanopore sensor, we could sensitively determine the protease activity in the serum within minutes, thus overcoming the lipid bilayer's short life-time limitation ${ }^{31}$. This same approach was utilized to analyze the mock trypsin serum sample in this work. Our experimental results showed that the trypsinspiked serum sample produced LVFF events with a similar frequency to that of the control sample (i.e., trypsin standard solution) (Supporting Information, Fig. S-5), supporting the feasibility of our developed nanopore sensor for potential clinical applications.

\section{Conclusions}

In summary, a new type of nanoscale-sized biosensor was developed to measure the activity of trypsin by monitoring the enzymatic reactions between the substrate and trypsin in an a- 
hemolysin nanopore. Compared with the time-consuming commercial assay kits, which typically use a two-antibody sandwich immunoassay approach, to detect trypsin, our developed label-free nanopore sensor is real time, and is more suitable for point-of-care applications. In particular, in our sensor design, we take advantage of the substrate cleavage site, and use the signal from the cleavage product instead of the substrate to measure the protease activity, thus achieving improved sensor selectivity and accuracy over the conventional activity-based protease assay. To the best of our knowledge, this is the first time for the nanopore sensing technology to be utilized for the quantitative determination of protease activity. Given the importance of proteases as valuable diagnostic or prognostic markers for a variety of diseases and as important targets for drug discovery, developing sensitive and selective sensors for other proteases, especially those of biological, pharmaceutical, and medical importance (e.g., prostate-specific antigen, beta-secretase, caspases, and so on), is highly desirable. The nanopore sensor design strategy developed in this work would serve as a generic approach for that purpose.

\section{Supplementary Material}

Refer to Web version on PubMed Central for supplementary material.

\section{Acknowledgments}

This work was financially supported by the National Institutes of Health (1R15GM110632).

\section{References}

1. Stoytcheva M, Zlatev R, Cosnier S, Arredondo M. Square Wave Voltammetric Determination of Trypsin Activity. Electrochim Acta. 2012; 76:43-47.

2. See WA, Smith JL. Urinary Levels of Activated Trypsin in Whole-Organ Pancreas Transplant Patients with Duodenocystostomies. Transplantation. 1991; 52:630-633. [PubMed: 1926341]

3. Artigas JMG, Garcia ME, Faure MRA, Gimeno AMB. Serum Trypsin Levels in Acute Pancreatic and Non-Pancreatic Abdominal Conditions. Postgrad Med J. 1981; 57:219-222. [PubMed: 7291099]

4. Braatz JA, Elias C, Finny JG, Tran H, McCaman M. Quantitation of Residual Trypsin in Cell-Based Therapeutics Using Immobilized a-1-Antitrypsin or SBTI in an ELISA Format. J Immunol Methods. 2015; 417:131-133. [PubMed: 25527344]

5. Hayden O, Haderspöck C, Krassnig S, Chen X, Dickert FL. Surface Imprinting Strategies for the Detection of Trypsin. Analyst. 2006; 131:1044-1050. [PubMed: 17047805]

6. Miao P, Liu T, Li X, Ning L, Yin J, Han K. Highly Sensitive, Label-Free Colorimetric Assay of Trypsin Using Silver Nanoparticles. Biosens Bioelectron. 2013; 49:20-24. [PubMed: 23708813]

7. Lake-Bakaar G, McKavanagh S, Rubio CE, Epstein O, Summerfield JA. Measurement of Trypsin in Duodenal Juice by Radioimmunoassay. Gut. 1980; 21:402-407. [PubMed: 7429303]

8. Yi Q, Liu Q, Gao F, Chen Q, Wang G. Application of an Electrochemical Immunosensor with a MWCNT/PDAA Modified Electrode for Detection of Serum Trypsin. Sensors. 2014; 14:1020310212. [PubMed: 24919018]

9. Srinivasan R, Huang X, Ng SL, Yao SQ. Activity-Based Fingerprinting of Proteases. Chembiochem. 2006; 7:32-36. [PubMed: 16317790]

10. Johnston D, Hermans JM, Yellowlees D. Isolation and Characterization of a Trypsin from the Slipper Lobster, Thenus Orientalis (Lund). Arch Biochem Biophys. 1995; 324:35-40. [PubMed: 7503556]

11. Kersey AD, Berkoff TA, Morey WW. Multiplexed Fiber Bragg Grating Strain-Sensor System with a Fiber Fabry-Perot Wavelength Filter. Opt Lett. 1993; 18:1370-1372. [PubMed: 19823386] 
12. Zhang H, Yu D, Zhao Y, Fan A. Turn-on Chemiluminescent Sensing Platform for Label-Free Protease Detection Using Streptavidin-Modified Magnetic Beads. Biosens Bioelectron. 2014; 61:45-50. [PubMed: 24846776]

13. Hu L, Han S, Parveen S, Yuan Y, Zhang L, Xu G. Highly Sensitive Fluorescent Detection of Trypsin Based on BSA-Stabilized Gold Nanoclusters. Biosens Bioelectron. 2012; 32:297-299. [PubMed: 22209331]

14. Ionescu RE, Cosnier S, Marks RS. Protease Amperometric Sensor. Anal Chem. 2006; 78:63276331. [PubMed: 16970305]

15. Mereuta L, Asandei A, Seo CH, Park Y, Luchian T. Quantitative Understanding of pH- and SaltMediated Conformational Folding of Histidine-Containing, $\beta$-Hairpin-Like Peptides, through Single-Molecule Probing with Protein Nanopores. ACS Appl Mater Interfaces. 2014; 6:1324213256. [PubMed: 25069106]

16. Chen P, Gu J, Brandin E, Kim YR, Wang Q, Branton D. Probing Single DNA Molecule Transport Using Fabricated Nanopores. Nano Lett. 2004; 4:2293-2298. [PubMed: 25221441]

17. Majd S, Yusko EC, Billeh YN, Macrae MX, Yang J, Mayer M. Applications of Biological Pores in Nanomedicine, Sensing, and Nanoelectronics. Curr Opin Biotechnol. 2010; 21:439-476. [PubMed: 20561776]

18. Movileanu L. Watching Single Proteins Using Engineered Nanopores. Protein Pept Lett. 2014; 21:235-246. [PubMed: 24370252]

19. Haque F, Li J, Wu H, Liang X, Guo P. Solid-State and Biological Nanopore for Real-Time Sensing of Single Chemical and Sequencing of DNA. Nano Today. 2013; 8:56-74. [PubMed: 23504223]

20. Shasha C, Henley RY, Stoloff DH, Rynearson KD, Hermann T, Wanunu M. Nanopore-Based Conformational Analysis of a Viral RNA Drug Target. ACS Nano. 2014; 8:6425-6430. [PubMed: 24861167]

21. Wang G, Wang L, Han Y, Zhou S, Guan X. Nanopore Stochastic Detection: Diversity, Sensitivity, and Beyond. Acc Chem Res. 2013; 46:2867-2877. [PubMed: 23614724]

22. Wang Y, Zheng D, Tan Q, Wang MX, Gu LQ. Nanopore-Based Detection of Circulating MicroRNAs in Lung Cancer Patients. Nat Nanotechnol. 2011; 6:668-674. [PubMed: 21892163]

23. Kakish J, Tavassoly O, Lee JS. Rasagiline, a Suicide Inhibitor of Monoamineoxidases, Binds Reversibly to a-Synuclein. ACS Chem Neurosci. 2015; 6:347-355. [PubMed: 25514361]

24. Wang S, Haque F, Rychahou PG, Evers M, Guo P. Engineered Nanopore of phi29 DNA-Packaging Motor for Real-Time Detection of Single Colon Cancer Specific Antibody in Serum. ACS Nano. 2013; 7:9814-9822. [PubMed: 24152066]

25. Han Y, Zhou S, Wang L, Guan X. Nanopore Back Titration Analysis of Dipicolinic Acid. Electrophoresis. 2014; 36:467-470. [PubMed: 25074707]

26. Liu A, Zhao Q, Guan X. Stochastic Nanopore Sensors for the Detection of Terrorist Agents: Current Status and Challenges. Anal Chim Acta. 2010; 675:106-115. [PubMed: 20800721]

27. Steffensen MB, Rotem D, Bayley H. Single-Molecule Analysis of Chirality in a Multicomponent Reaction Network. Nat Chem. 2014; 6:603-607. [PubMed: 24950330]

28. Kang XF, Cheley S, Guan X, Bayley H. Stochastic Detection of Enantiomers. J Am Chem Soc. 2006; 128:10684-10685. [PubMed: 16910655]

29. Wang G, Zhao Q, Kang X, Guan X. Probing Mercury (II)-DNA Interactions by Nanopore Stochastic Sensing. J Phys Chem B. 2013; 117:4763-4769. [PubMed: 23565989]

30. Wang G, Wang L, Han Y, Zhou S, Guan X. Nanopore Detection of Copper Ions Using a Polyhistidine Probe. Biosens Bioelectron. 2014; 53:453-458. [PubMed: 24211457]

31. Wang L, Han Y, Zhou S, Guan X. Real-Time Label-Free Measurement of HIV-1 Protease Activity by Nanopore Analysis. Biosens Bioelectron. 2014; 62:158-162. [PubMed: 24997370]

32. Kukwikila M, Howorka S. Electrically Sensing Protease Activity with Nanopores. J Phys Condens Matter. 2010; 22:454103. [PubMed: 21339591]

33. Kasianowicz JJ, Brandin E, Branton D, Deamer DW. Characterization of Individual Polynucleotide Molecules Using a Membrane Channel. Proc Nat Acad Sci. 1996; 93:13770-13773. [PubMed: 8943010] 
34. Wang Y, Montana V, Grubišić V, Stout RF Jr, Parpura V, Gu LQ. Nanopore Sensing of Botulinum Toxin Type B by Discriminating an Enzymatically Cleaved Peptide from a Synaptic Protein Synaptobrevin 2 Derivative. ACS Appl Mater Interfaces. 2015; 7:184-192. [PubMed: 25511125]

35. Montal M, Mueller P. Formation of Bimolecular Membranes from Lipid Monolayers and a Study of Their Electrical Properties. Proc Nat Acad Sci. 1972; 69:3561-3566. [PubMed: 4509315]

36. Zhao Q, Jayawardhana DA, Wang D, Guan X. Study of Peptide Transport through Engineered Protein Channels. J Phys Chem B. 2009; 113:3572-3578. [PubMed: 19231820]

37. Zhao Q, de Zoysa RS, Wang D, Jayawardhana DA, Guan X. Real-Time Monitoring of Peptide Cleavage Using a Nanopore Probe. J Am Chem Soc. 2009; 131:6324-6325. [PubMed: 19368382]

38. Song LZ, Hobaugh MR, Shustak C, Cheley S, Bayley H, Gouaux JE. Structure of Staphylococcal a-Hemolysin, a Heptameric Transmembrane Pore. Science. 1996; 274:1859-1866. [PubMed: 8943190]

39. Diaz JF, Balkus KJ Jr. Enzyme Immobilization in MCM-41 Molecular Sieve. J Mol Catal B Enzym. 1996; 2:115-126.

40. Morari D, Stepurina T, Rotari VI. Calcium Ions Make Phytohemagglutinin Resistant to Trypsin Proteolysis. J Agric Food Chem. 2008; 56:3764-3771. [PubMed: 18459789]

41. Sipos T, Merkel JR. Effect of Calcium Ions on the Activity, Heat Stability, and Structure of Trypsin. Biochem. 1970; 9:2766-2775. [PubMed: 5466615]

42. Singh M, Krikorian AD. Inhibition of Trypsin Activity in vitro by Phytate. J Agric Food Chem. 1982; 30:799-800.

43. Papaleo E, Fantucci P, de Gioia L. Effects of Calcium Binding on Structure and Autolysis Regulation in Trypsins. A Molecular Dynamics Investigation. J Chem Theory Comput. 2005; 1:1286-1297. [PubMed: 26631672]

44. Cupp-Enyard C. Sigma's Non-specific Protease Activity Assay - Casein as a Substrate. J Vis Exp. 2008; 19:e899.

45. Laskowski M Jr, Kato I. Protein Inhibitors of Proteinases. Annu Rev Biochem. 1980; 49:593-526. [PubMed: 6996568]

46. Kukwikila M, Howorka S. Nanopore-Based Electrical and Label-Free Sensing of Enzyme Activity in Blood Serum. Anal Chem. 2015; 87:9149-9154. [PubMed: 26305576] 
a

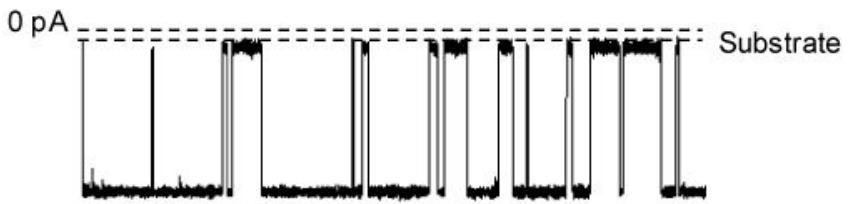

b

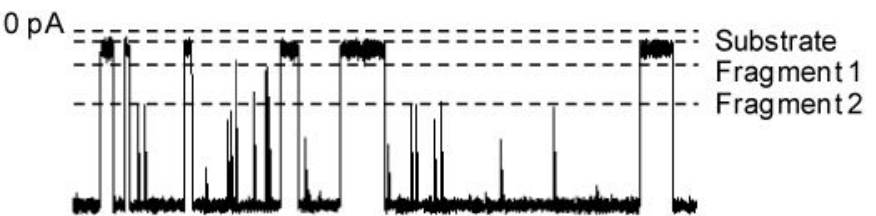

C

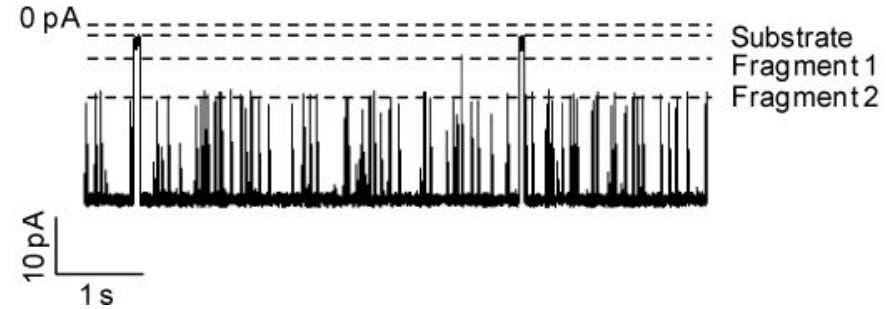

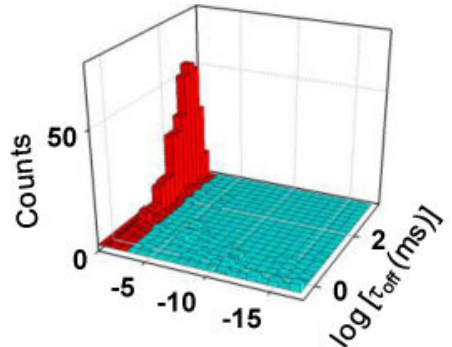
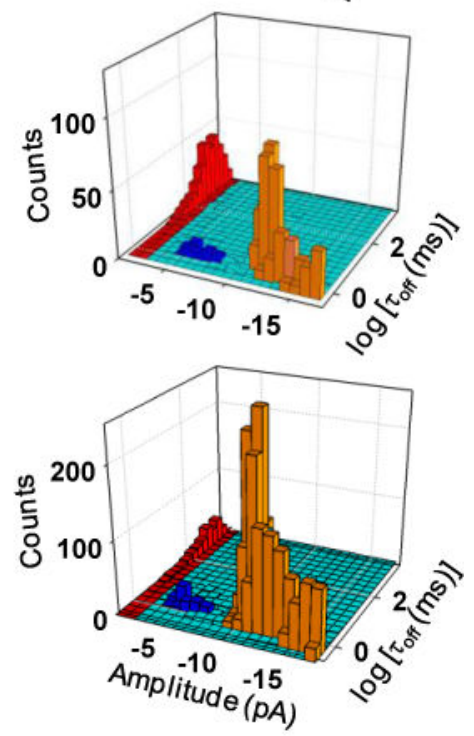

Figure 1.

Nanopore measurement of trypsin activity: (a) $0 \mathrm{ng} / \mathrm{mL}$; (b) $10 \mathrm{ng} / \mathrm{mL}$; and (c) $100 \mathrm{ng} / \mathrm{mL}$. (Left) Typical single-channel recording trace segments after 30-min proteolytic cleavage of peptide $\beta$-amyloid (10-20). Dashed lines represent the levels of zero current, and residual currents of the substrate (peptide sequence: YEVHHQKLVFF) and its two cleavage products (the sequence of fragment 1: YEVHHQK, and that of fragment 2: LVFF); (Right) the corresponding 3D plots of event count vs. residence time vs. blockage amplitude, showing the significant difference in the signatures of the blockage events attributed to the peptide substrate (red), fragment 1 (blue), and fragment 2 (yellow). The experiments were performed at $-40 \mathrm{mV}$ in $1 \mathrm{M} \mathrm{NaCl}$ solution buffered with $10 \mathrm{mM}$ Tris ( $\mathrm{pH}$ 7.5) using the mutant ahemolysin protein $(\mathrm{M} 113 \mathrm{~F})_{7}$ pore. The concentration of the substrate $\beta$-amyloid (10-20) was $5 \mu \mathrm{M}$. 


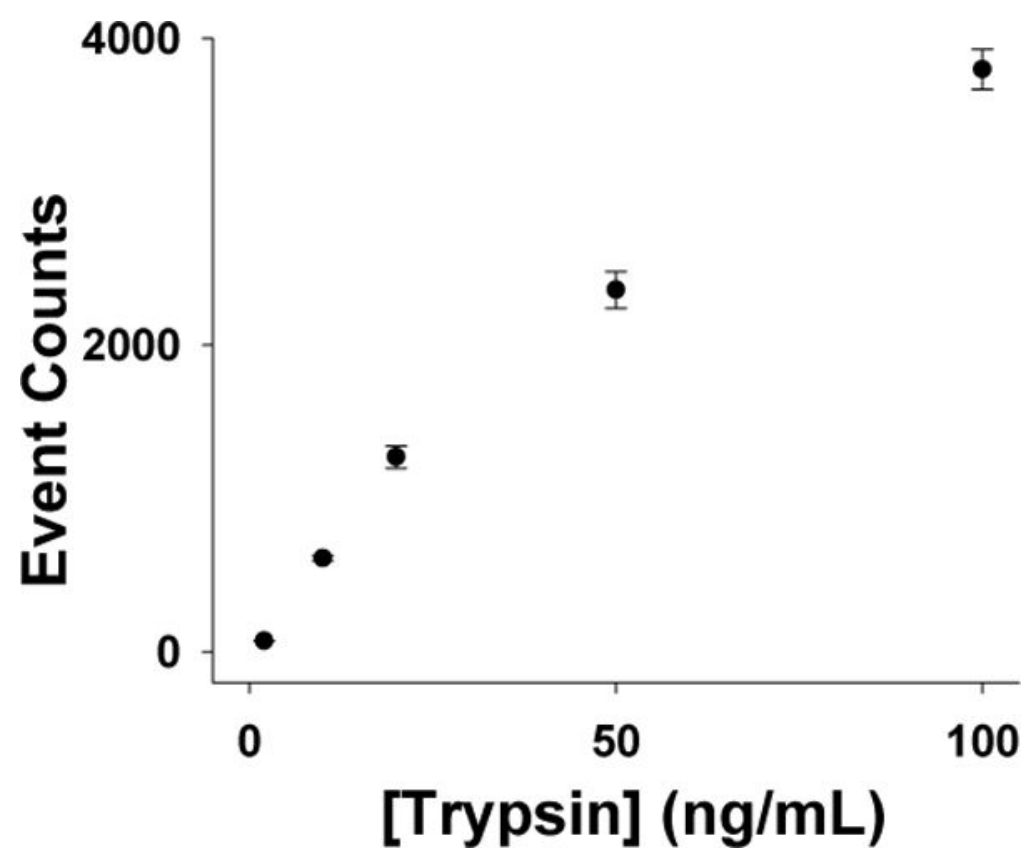

Figure 2.

Dose-response curve for trypsin detection. The experiments were performed with the $(\mathrm{M} 113 \mathrm{~F})_{7} \mathrm{a}$-hemolysin pore in a buffer solution comprising $1.0 \mathrm{M} \mathrm{NaCl}$ and $10 \mathrm{mM}$ Tris ( $\mathrm{pH} 7.5$ ) at $-40 \mathrm{mV}$ in the presence of $5 \mu \mathrm{M} \beta$-amyloid (10-20). The data analysis was performed based on 30 min trace segments. 
a

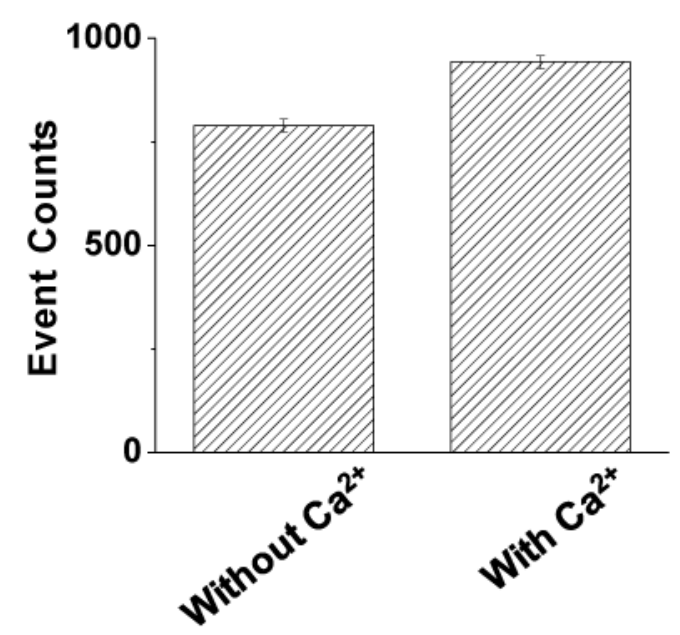

b

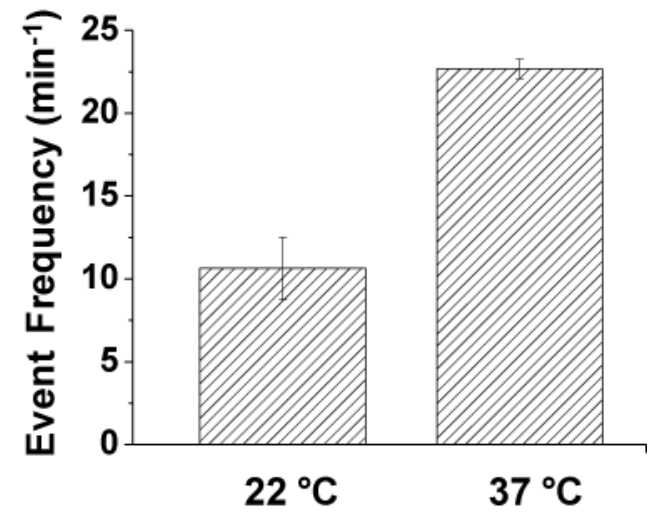

Figure 3.

Effects of (a) $\mathrm{Ca}^{2+}$ ions and (b) temperature on the trypsin sensor sensitivity. The experiments were performed using the $(\mathrm{M} 113 \mathrm{~F})_{7}$ a-hemolysin pore in a buffer solution comprising $1.0 \mathrm{M} \mathrm{NaCl}$ and $10 \mathrm{mM}$ Tris $(\mathrm{pH} \mathrm{7.5)}$ at $-40 \mathrm{mV}$ in the absence and presence of $5 \mathrm{mM} \mathrm{Ca}^{2+}$, and at $22{ }^{\circ} \mathrm{C}$ or $37{ }^{\circ} \mathrm{C}$, respectively. The concentrations of trypsin shown in Figs. $3 \mathrm{a}$ and $3 \mathrm{~b}$ were $10 \mathrm{ng} / \mathrm{mL}$ and $50 \mathrm{ng} / \mathrm{mL}$, respectively. Event counts shown in Fig. 3a were calculated based on the last 20 min trace segments of 30-min single channel recordings. 

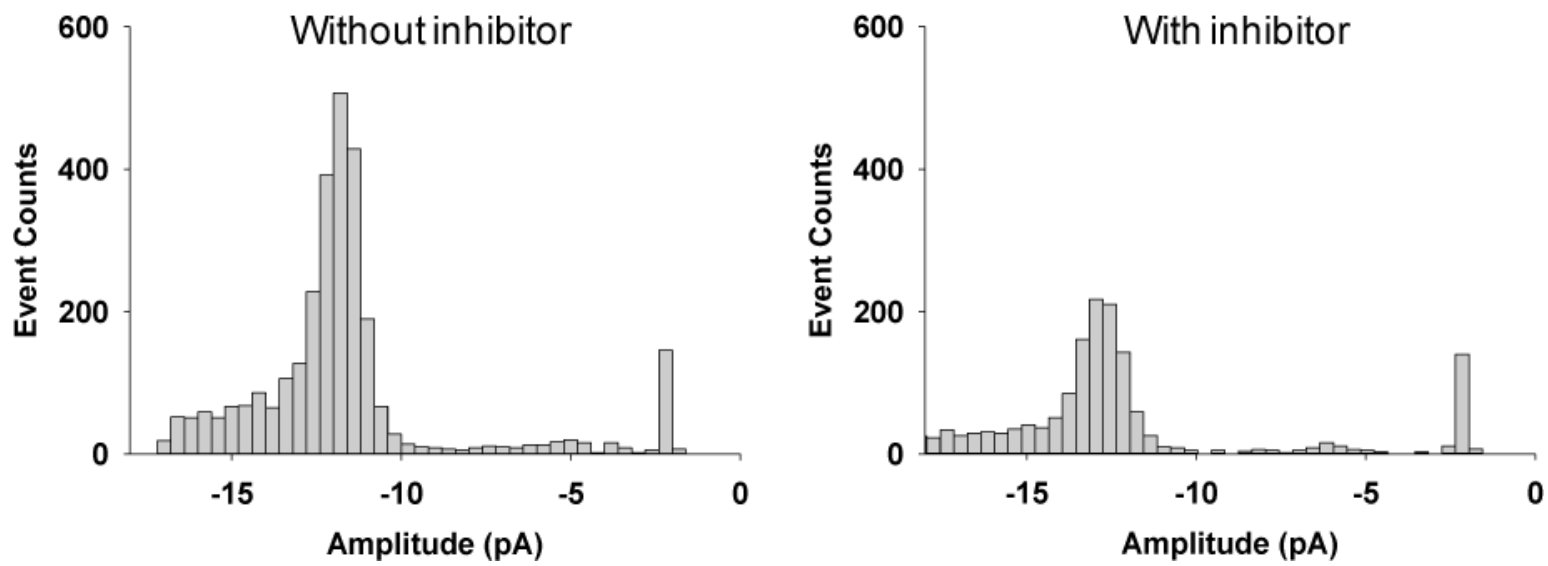

Figure 4.

Effect of inhibitor on trypsin digestion of $\beta$-amyloid (10-20). The experiments were performed with the $(\mathrm{M} 113 \mathrm{~F})_{7}$ a-hemolysin pore in a buffer solution comprising $1.0 \mathrm{M} \mathrm{NaCl}$ and $10 \mathrm{mM}$ Tris $(\mathrm{pH} \mathrm{7.5)}$ at $-40 \mathrm{mV}$ in the presence of $5 \mu \mathrm{M} \beta$-amyloid (10-20) and 100 $\mathrm{ng} / \mathrm{mL}$ trypsin. The concentration of the inhibitor was $0.125 \mathrm{nM}$. Data analysis was performed based on 456-s trace segments after 30-min proteolytic cleavage of $\beta$-amyloid (10-20) by trypsin and the trypsin/inhibitor mixture. In the latter case, trypsin and trypsin inhibitor were incubated at $37^{\circ} \mathrm{C}$ for 10 min before performing the substrate digestion experiment. 


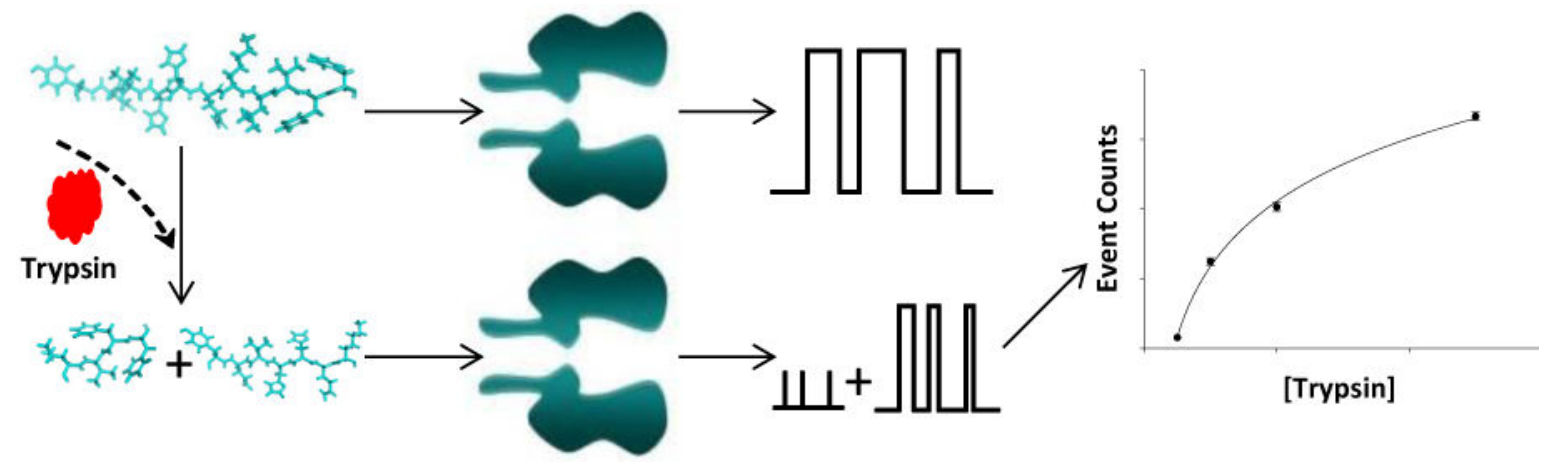

Scheme 1.

Schematic representation of the principle of nanopore detection of trypsin. The interaction of the substrate cleavage products with the nanopore produces current modulation events having significantly different signatures from those attributed to the translocation of the substrate peptide in the nanopore. A comparison of these events quantifies the trypsin activity. 


\section{Table 1}

Determination of trypsin activity using a nanopore single-molecule biosensor

\begin{tabular}{cll}
\hline Trypsin Concentration (ng/mL) & Trypsin Activity (Units) & Relative deviation (\%) \\
\hline 2 & $9.8 \times 10^{-6}$ & 1.01 \\
10 & $8.5 \times 10^{-5}$ & 2.83 \\
20 & $1.8 \times 10^{-4}$ & 5.60 \\
50 & $3.6 \times 10^{-4}$ & 13.3 \\
100 & $5.3 \times 10^{-4}$ & 3.47 \\
\hline
\end{tabular}

* The activity of trypsin was determined in terms of Units, which is the amount in micromoles of the LVFF fragment released from trypsin digestion of the peptide substrate $\beta$-amyloid (10-20) per minute. The data analysis was performed based on 30 min trace segments. 